University of Nebraska - Lincoln

DigitalCommons@University of Nebraska - Lincoln

Papers in Natural Resources

Natural Resources, School of

2007

Vegetative and Invertebrate Community

Characteristics of Conservation Reserve Program Fields Relative to Gamebirds in Western Kansas

Elizabeth D. Doxon

Oklahoma State University, elizabeth.doxon@okstate.edu

John P. Carroll

University of Georgia, jcarroll2@unl.edu

Follow this and additional works at: http://digitalcommons.unl.edu/natrespapers

Part of the Natural Resources and Conservation Commons, Natural Resources Management and Policy Commons, and the Other Environmental Sciences Commons

Doxon, Elizabeth D. and Carroll, John P., "Vegetative and Invertebrate Community Characteristics of Conservation Reserve Program Fields Relative to Gamebirds in Western Kansas" (2007). Papers in Natural Resources. 659.

http://digitalcommons.unl.edu/natrespapers/659

This Article is brought to you for free and open access by the Natural Resources, School of at DigitalCommons@University of Nebraska - Lincoln. It has been accepted for inclusion in Papers in Natural Resources by an authorized administrator of DigitalCommons@University of Nebraska - Lincoln. 


\title{
Vegetative and Invertebrate Community Characteristics of Conservation Reserve Program Fields Relative to Gamebirds in Western Kansas
}

\author{
ELIZABETH D. DOXON ${ }^{1}$ AND JOHN P. CARROLL \\ Warnell School of Forestry and Natural Resources, University of Georgia, Athens 30605
}

\begin{abstract}
We examined vegetation and invertebrate characteristics, including insect biomass, insect-prey, six Families and seven Orders in four varieties of Conservation Reserve Program (CP10, improved CP10, CP2 and CP25) and wheat fields in western Kansas during Jun. and Jul., 2004 and 2005 relative to gamebird chick ecology. CP10 fields had less bare ground and forbs compared to the other Conservation Practices and CP25 fields had lost much of their original forb component by the end of the study. Although there was little forb component, CP10 fields had high invertebrate biomass. However, CP10 fields demonstrated sizeable declines in the estimated effect size of examined invertebrate characteristics between sampling periods unlike the other mixes. Unharvested wheat (Triticum aestivum), CP10 and improved CP10 fields had the greatest number of insect-prey. Overall, most fields had adequate insect-prey availability suggesting that in terms of insect availability for gamebird chicks, these fields provide excellent brood feeding opportunities, therefore accessibility and other issues might be more important in determining habitat "quality" for gamebird chicks.
\end{abstract}

\section{INTRODUCTION}

In the United States, over 12.8 million ha of farmland have been converted to semipermanent grasses and other perennial plantings through the Conservation Reserve Program (CRP) with the goals of reducing soil erosion and regulating crop production (USDA, 2001). As of Jan. 2006, Kansas accounts for roughly $9 \%$ of this total with over 1.1 million ha of farmland enrolled in the program, with $60 \%$ of these fields located in western Kansas (USDA, 2006). Several Conservation Practices (CP) are available for planting in Kansas including Conservation Practice 10 (CP10, Established Grass), Conservation Practice 2 (CP2, Native Grasses) and Conservation Practice 25 (CP25, Rare and Declining Habitat). Producers also have the option of interseeding alfalfa (Medicago sativa) and sweet clover (Melilotus spp.) into previously established CP10 fields (improved CP10).

The use of the CRP fields by both game and non-game birds has been well-documented (King and Savidge, 1995; Delisle and Savidge, 1997; Best et al., 1998). In Kansas, declining grassland birds, such as the grasshopper sparrow (Ammodramus savannarum), lark bunting (Calamospiza melanocorys), dickcissel (Spiza americana) and lesser prairie-chicken (Tympanuchus pallidicinctus), and economically important gamebirds, such as the northern bobwhite (Colinus virginianus) and ring-necked pheasant (Phasianus colchicus) are known to utilize the CRP fields (Johnson and Schwartz, 1993; Hull et al., 1996; Delisle and Savidge, 1997; Hughes et al., 2000).

During the nesting and chick-rearing season, these birds require a large proportion of invertebrate protein in their diet (Wiens and Rotenberry, 1979). Insects have more than four times the protein as compared to plants and contain essential amino acids not present in plant protein. Insect protein is also more easily assimilated compared to plant protein

\footnotetext{
${ }^{1}$ Corresponding author: present address: Oklahoma Cooperative Fish and Wildlife Research Unit, 404 Life Sciences West, Oklahoma State University, Stillwater, Oklahoma 74078; Telephone: (405)7446342; e-mail: elizabeth.doxon@okstate.edu
} 
(Potts, 1986; Moreby, 2003). It has been demonstrated that gamebird chicks will select particular Families of invertebrates. In pheasants, insect-prey may include grasshoppers (Orthoptera: Acrididae), leafhoppers (Homoptera: Cicadellidae), planthoppers (Homoptera: Flatidae), plant bugs (Hemiptera: Miridae) and flies (Diptera) (Whitmore et al., 1986). Bobwhite chicks may select beetles (Coleoptera), leafhoppers, plant bugs, spiders (Araneae), grasshoppers, ants (Hymenoptera: Formicidae) and flies (Handley, 1931; Landers and Mueller, 1986; Jackson et al., 1987).

Among the various Conservation Practices within the CRP, it has been shown that vegetation characteristics will vary among practices, and it is suggested that these structural differences may indirectly influence invertebrate prey availability to gamebird chicks (Burger et al., 1993; McIntyre and Thompson, 2003). Previous studies suggest that plants classified as forbs tend to be associated with higher invertebrate populations than grass, bare ground and shrubs (Hill, 1985; Burger et al., 1993; Jamison et al., 2002). These studies suggest that Conservation Practices which incorporate forbs will provide the greatest invertebrate benefit and therefore be more beneficial wildlife habitat. However, the relative importance of forbs in affecting invertebrate abundance is still under discussion (Hull et al., 1996). Issues such as landscape context may also affect invertebrate abundance (Stoner and Joern, 2004). As a result, vegetation characteristics alone may not be good variables in predicting habitat quality for gamebird chicks. With these issues in mind, we compared the vegetation and structural characteristics of four Conservation Practices (CP10, improved CP10, CP2 and CP25) that provided grassland cover and identified which of these Conservation Practices had the greatest invertebrate abundances compared to wheat during 2 mo of the critical chick rearing period of northern bobwhites and ring-necked pheasants. As no studies pertaining to CP25 vegetative structure and invertebrate characteristics exist, we were particularly interested in how this mix may differ from the others.

\section{Conservation Practices}

Fields selected for enrollment in CRP are enrolled in the program for 10-15 y contracts. In Kansas, as well as other states, these fields have historically been left unmanaged for the length of the contract; however, with the 2002 Farm Bill, mid-contract management is now required for newly established fields (USDA, 2005). Under extenuating circumstances, these fields may be emergency hayed or grazed. None of the fields used in the study had been hayed, burned or grazed in the previous $3 \mathrm{y}$.

Four Conservation Practices were examined in this study: CP10, CP2, CP25 and improved CP10. CP10 fields were sown with native grasses, such as western wheatgrass (Pascopyrum smithii), indiangrass (Sorghastrum nutans), switchgrass (Panicum virgatum), side-oats grama (Bouteloua curtipendula), little bluestem (Schizachyrium scoparium) and big bluestem (Andropogon gerardii). CP2 fields were planted to native grasses with an additional forb component, usually alfalfa (Medicago sativa). CP25 mixes were comprised of native grasses and include the addition of wildflowers, such as Maximillian sunflower (Helianthus maximiliani), purple prairie clover (Dalea lasiathera), prairie coneflower (Ratiba columnifera) and Illinois bundleflower (Desmanthus illinoensis) (Kansas Department of Wildlife and Parks, 2003).

Because previous studies have demonstrated that forbs may provide better invertebrate substrate, some CP10 fields have had alfalfa interseeded into previously established grasses (improved CP10). In general, CP10 and improved CP10 fields are older (7-10 y into contract) than CP2 and CP25 which tend to be much younger ( $3-5$ y into contract). Interseeding of the improved CP10 fields occurred 3-5 y prior to the study. Fields may have 

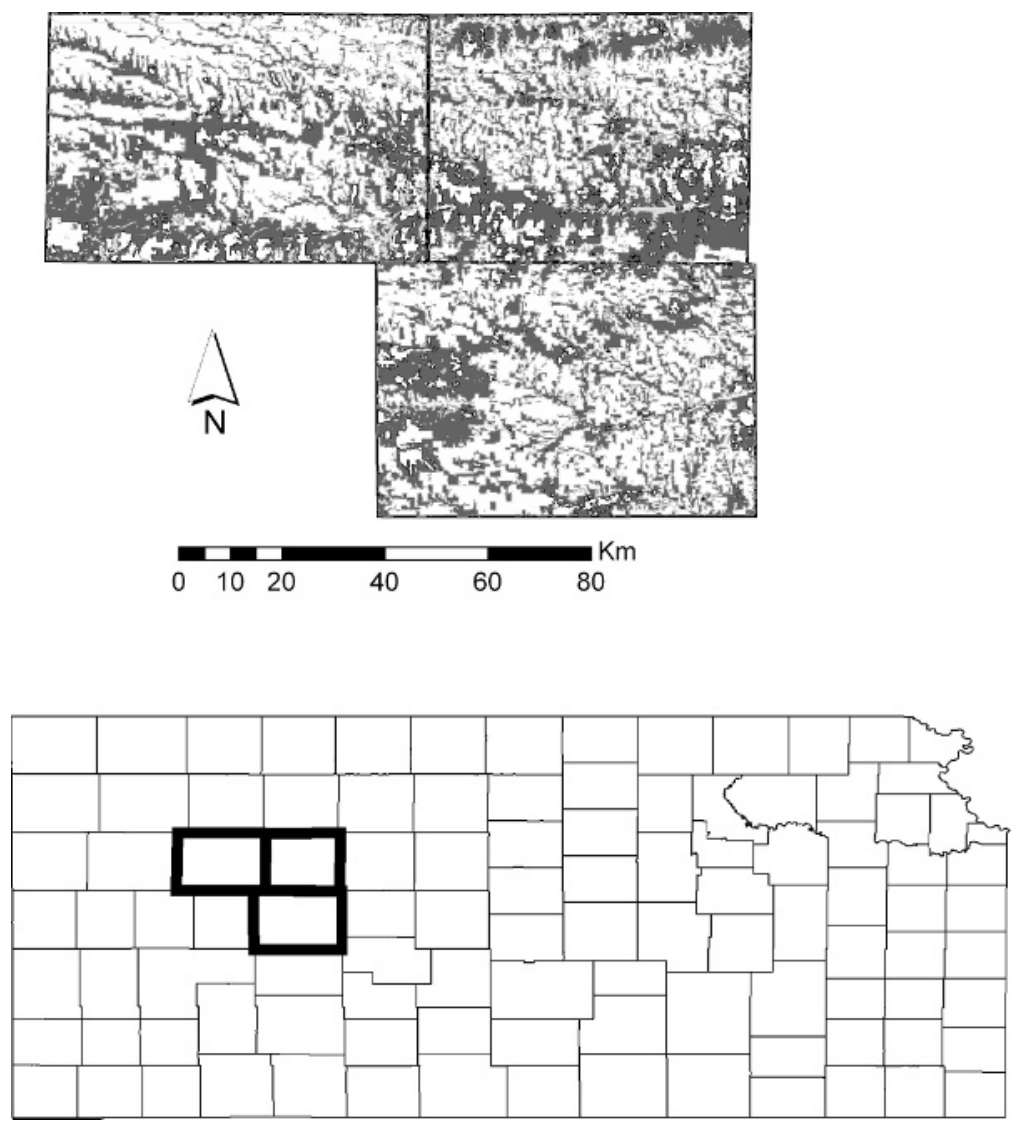

FIG. 1.-The study area was located in portions of 3 western Kansas counties: southeastern Gove, southwestern Trego, and northwestern Ness. Areas in black represent grasslands, white areas represent croplands, and grey areas represent other land uses

been prepared for interseeding by mowing or tilling the area which was to be interseeded. Forbs were then planted with a conventional drill or a no-till drill. Of note, a large portion of the CRP fields in 2004 were dominated by wild yellow sweet clover (Melilotus officinalis) (E. Doxon, pers. obs.). Field sizes in the study ranged from 32-259 ha.

\section{Methods \\ STUDY AREA}

The study was conducted in Gove, Ness and Trego counties centered on Utica $\left(38^{\circ} 37^{\prime \prime} \mathrm{N}\right.$, $100^{\circ} 07^{\prime \prime} \mathrm{W}$, elev. $798 \mathrm{~m}$ ) in western Kansas during Jun. and Jul., 2004 and 2005 (Fig. 1). Among the three counties, cropland accounted for $56.8 \%$ of the land use and grassland/ rangeland accounted for $42.2 \%$ with the remaining $1 \%$ in residential and commercial use (Kansas Geological Survey, 2003). The predominant crops grown include winter wheat, sorghum (Sorghum vulgar) and dryland corn (Zea mays) (National Agricultural Statistics Service, 2002). The average annual precipitation is $550 \mathrm{~mm}$, with $75 \%$ of the precipitation 
occurring between Apr. and Sep. However, during the last 2 wk of Jun. and beginning of Jul. 2004, the study area received 304-406 mm of rain (Weather Data Library, 2005). In general, wheat harvest in this area begins the last week of Jun. However, in 2004, droughty conditions precipitated an earlier than usual harvest. Therefore, both sampling occasions in this year reflected the harvested condition. In 2005, Jun. reflected unharvested wheat whereas Jul. reflected harvested wheat.

As of Oct. 2003, 49425 ha of grassland were enrolled in the Conservation Reserve Program in the three counties. This accounted for $4.3 \%, 4.6 \%$ and $9.6 \%$ of the land area for Trego, Gove and Ness County, respectively (USDA, 2006). We randomly selected five areas that were used as blocks. In these five blocks, we randomly selected one wheat field and one field for each Conservation Practice being examined (five fields per field-type for a total of 25 experimental units). Due to the biennial nature of the wheat-fallow system in western Kansas, different wheat fields were sampled in 2004 and 2005. Due to emergency grazing, two CP2 fields were substituted using the same methodology in 2005.

\section{VEGETATION AND INVERTEBRATE SAMPLING}

We randomly selected four 10-m line transects in each field and sampled the vegetation and structural characteristics on four equally-spaced $1-\mathrm{m}^{2}$ quadrats within each transect for a total of 16 sampling points within each field. Sampling occurred once during each period of 11-21 Jun. and 9-22 Jul. 2004 and once during each period of 9-22 Jun. and 11-21 Jul. 2005 in either the early morning (0900-1030) or early evening (1700-2000). At each sampling point, we visually estimated cover of forb, grass and bare ground to the nearest $5 \%$ and estimated vertical density to the nearest $0.5 \mathrm{dm}$ by taking a visual obstruction reading [height-density index (VOR)] with a Robel pole in the four cardinal directions from the center of the quadrat (Robel et al., 1970). On the same transects, we collected invertebrates using vacuum sampling (Dietrick, 1961). Vacuum sampling may be biased towards lighterbodied insects and underestimate heavier-bodied insects such as Acrididae (Buffington and Redak, 1998); however, vacuum sampling is appropriate in this case due to the ability to sample insects along the ground and on low vegetation where chicks are most likely to forage (Cooper and Whitmore, 1990). The collected invertebrates were killed by freezing, identified to family (except for Lepidoptera larvae which were identified to Order) and counted. For each transect, invertebrates were dried and weighed to the nearest $0.001 \mathrm{~g}$. For analysis, transects were pooled to provide an overall field estimate.

\section{DATA ANALYSIS}

For vegetation analysis, effect of sampling occasion was analyzed with a repeated measures analysis of variance for each year separately using month as the repeated variable. We normalized forb, grass and bare ground percentages with an arcsine square root transformation. We averaged 16 transformed sampling points to produce an overall value for each field. We examined vegetation variables for each trial separately with orthogonal contrasts using a Bonferonni correction for multiple tests $(P=0.01)$. These contrasts included comparing CRP fields to wheat, comparing CP10 fields to the remaining practices (CP2, improved CP10 and CP25) [grass vs. forbs], comparing improved CP10 to CP2 [interseeding vs. mix addition] and comparing improved CP10 and CP2 to CP25 [alfalfa vs. wildflowers]. Preliminary analysis determined that block was not a significant effect, therefore block sums of squares and degrees of freedom were added to the error term. We back-transformed end results for graphical presentation.

We compared invertebrate biomass (pooled transects) and the abundances of six Families (Acrididae, Carabidae, Chrysomelidae, Curculionidae, Formicidae and Nabidae) and seven 


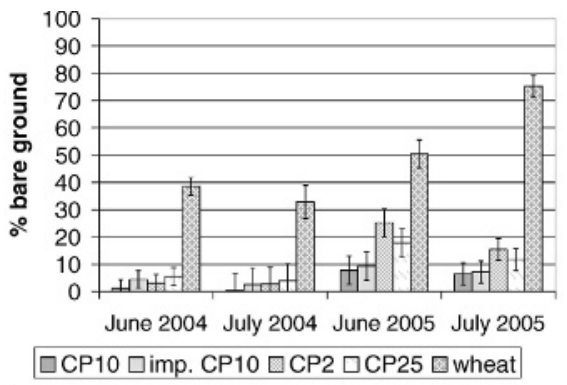

a)

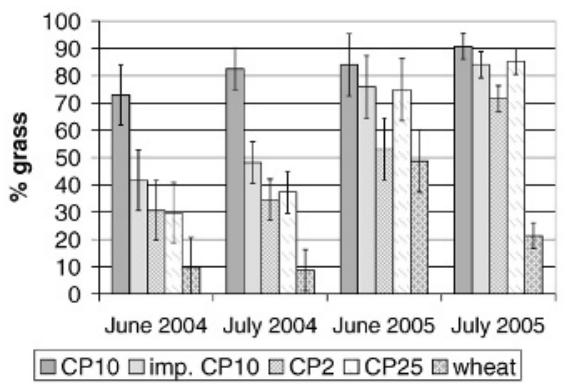

b)

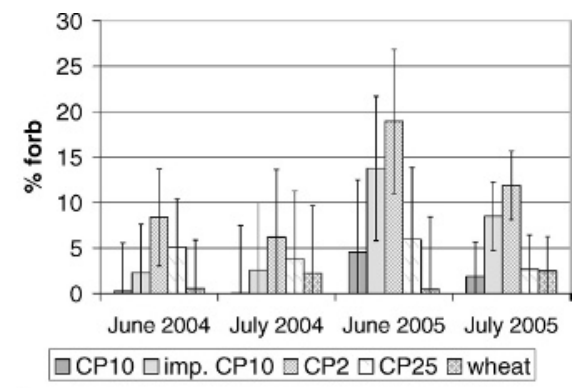

c)

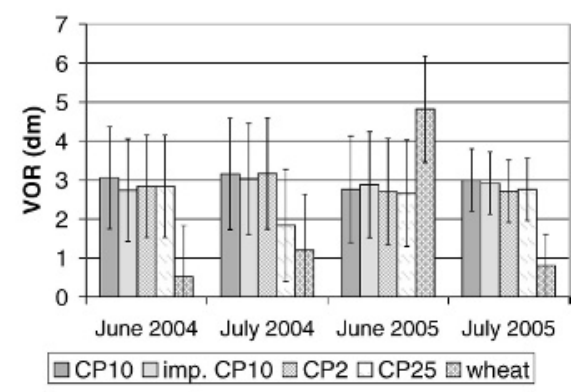

d)

FIG. 2.-a) Mean bare ground cover ( $\pm 95 \%$ CI $)$, b) mean grass cover $( \pm 95 \%$ CI $)$, c) mean forb cover $( \pm 95 \% \mathrm{CI})$, and d) mean height-density indexes (VORs, $\pm 95 \% \mathrm{CI}$ ) measured in the 4 Conservation Practices and wheat in western Kansas, Jun. and Jul., 2004 and 2005

Orders (Araneae, Coleoptera, Hemiptera, Homoptera, Hymenoptera, Lepidoptera larvae and Orthoptera). These Families and Orders were chosen as they were identified as important dietary items for both ring-necked pheasant and bobwhite chicks during a concurrent feeding ecology study (Doxon, 2005). We examined the effect of sampling occasion with a repeated measures analysis of variance within PROC Mixed (SAS Institute, 1999) for each year separately using month as the repeated variable. Percent forb was used as a covariate in the analyses (except for Carabidae in which we used percent ground). Additionally, we estimated the effect size for the four orthogonal contrasts for each sampling occasion for each year separately and corrected for multiple tests using a Bonferonni correction. We also compared the number of greater quality insect-prey identified in each field. Insects which were identified in the diet of human-imprinted pheasant and bobwhite chicks were classified as greater quality insects and invertebrates identified in the vacuum samples but not identified in the diet of either species were classified as lesser quality insects. (see Appendix 1 for prey quality classifications).

\section{RESULTS}

\section{VEGETATION}

In 2004 bare ground cover in the Conservation Practices averaged $<10 \%$; however, in 2005, bare ground cover remained low except for CP2 and CP25 with average bare ground $\sim 20 \%$ (Fig. 2a). Bare ground cover did not vary between the 2 sampling occasions in 2004 
TABLE 1.-Test statistics (F-test) for mean vegetation structural characteristics measured in the 4 Conservation Practices and wheat in western Kansas, Jun. and Jul., 2004 and 2005

\begin{tabular}{lccc}
\hline \hline Vegetative characteristic & Year & Between sampling periods & P-value \\
\hline Bare ground $^{\mathrm{a}}$ & 2004 & 1.38 & 0.2 \\
& 2005 & 0.04 & 0.8 \\
Grass $^{\mathrm{a}}$ & 2004 & 5.47 & $0.003^{\mathrm{b}}$ \\
& 2005 & 2.49 & 0.1 \\
Forb $^{\mathrm{a}}$ & 2004 & 0.01 & 0.9 \\
& 2005 & 3.08 & 0.09 \\
VOR $^{\mathrm{a}}$ & 2004 & 0.25 & 0.6 \\
& 2005 & 31.2 & $<0.0001^{\mathrm{b}}$ \\
\hline
\end{tabular}

\footnotetext{
${ }^{\mathrm{a}}$ Degrees of freedom $=4$

b Significant difference at $\alpha=0.05$
}

or 2005 (Table 1). There was more bare ground cover in the wheat fields compared to the Conservation Practices during Jun. $2004\left(t_{1,24}=104.0, \mathrm{P}<0.0001\right)$, Jul. $2004\left(t_{1,24}=48.5, \mathrm{P}\right.$ $<0.0001)$, Jun. $2005\left(t_{1,24}=43.8, \mathrm{P}<0.0001\right)$ and Jul. $2005\left(t_{1,24}=186.0, \mathrm{P}<0.0001\right)$. In Jun. 2005 there was more bare ground cover in the CP2 fields compared to the improved CP10 fields $\left(t_{1,24}=7.9, \mathrm{P}=0.01\right)$.

Grass was the dominate cover in 2004 and 2005 (Fig. 2b). Grass cover varied between the two sampling occasions in 2004, but did not vary between the two sampling occasions in 2004 or 2005 (Table 1). There was more grass cover in the CRP fields compared to wheat in Jun. $2004\left(t_{1,24}=20.6, \mathrm{P}=0.0002\right)$, Jul. $2004\left(t_{1,24}=45.6, \mathrm{P}<0.0001\right)$, Jun. $2005\left(t_{1,24}=\right.$ $7.4, \mathrm{P}=0.01)$ and Jul. $2005\left(t_{1,24}=132.9, \mathrm{P}<0.0001\right) . \mathrm{CP} 10$ fields had more grass cover compared to the other Conservation Practices in Jun. $2004\left(t_{1,24}=18.9, \mathrm{P}=0.0003\right)$ and Jul. $2004\left(t_{1,24}=35.6, \mathrm{P}<0.0001\right)$.

Forb cover was highly variable in both 2004 and 2005 (Fig. 2c). Forb cover did not vary between the 2 sampling occasions in 2004 or 2005 (Table 1). CP10 fields had less forb cover compared to the other Conservation Practices in Jun. $2004\left(t_{1,24}=7.5, \mathrm{P}=0.01\right)$. In Jun. 2005 the CRP fields had more forb cover compared to wheat $\left(t_{1,24}=11.2, \mathrm{P}=0.003\right)$. In Jul. 2005 improved CP10 and CP2 fields had more forb cover compared to CP25 fields $\left(t_{1,24}=\right.$ 8.0, $\mathrm{P}=0.01$ ).

Height-density indexes for all the Conservation Practices remained fairly constant in 2004 and 2005 (Fig. 2d). The height-density indexes did not vary between the two sampling occasions in 2004, but did vary between the two sampling occasions in 2005 (Table 1). CRP fields were taller than wheat fields in Jun. $2004\left(t_{1,24}=46.0, \mathrm{P}<0.0001\right)$, Jul. $2004\left(t_{1,24}=\right.$ 17.7, $\mathrm{P}=0.0004)$, Jun. $2005\left(t_{1,24}=33.0, \mathrm{P}<0.0001\right)$ and Jul. $2005\left(t_{1,24}=92.6, \mathrm{P}<\right.$ $0.0001)$.

\section{INVERTEBRATE COMMUNITIES}

Invertebrate biomass did not vary over time in 2004 or 2005 (Table 2) (Fig. 3a). In Jun. 2004 wheat fields had less invertebrate biomass than CRP fields $\left(t_{1,24}=19.5, \mathrm{P}=0.0003\right)$. CRP fields produced $1.1 \pm 0.5 \mathrm{~g}$ /field more biomass than wheat fields. In Jul. 2004 CP10 fields had less biomass than the remaining Conservation Practices $\left(t_{1,24}=4.4, \mathrm{P}=0.04\right)$. Improved CP10, CP2 and CP25 produced $0.8 \pm 0.7 \mathrm{~g} /$ field more biomass than CP10 fields. In Jun. 2005 CP25 fields had less biomass compared to improved CP10 and CP2 fields $\left(t_{1,24}\right.$ $=6.1, \mathrm{P}=0.02)$. Improved CP10 and CP2 fields produced $0.5 \pm 0.4 \mathrm{~g} /$ field more biomass than wildflower fields. In Jul. 2005 CP25 fields had less biomass compared to improved CP10 
TABLE 2.-Test statistics (F-test) for mean abundances measured in the four Conservation Practices and wheat for number of insect-prey, invertebrate biomass, six insect Families in western Kansas, Jun. and Jul., 2004 and 2005

\begin{tabular}{lccl}
\hline \hline Invertebrate characterisitc & Year & Between sampling period & P-value \\
\hline Biomass $^{\mathrm{a}}$ & 2004 & 1.82 & 0.1 \\
& 2005 & 2.21 & $0.01^{\mathrm{b}}$ \\
Insect-prey $^{\mathrm{a}}$ & 2004 & 1.26 & 0.3 \\
& 2005 & 20.76 & $0.0002^{\mathrm{b}}$ \\
Acrididae $^{\mathrm{a}}$ & 2004 & 4.33 & $0.04^{\mathrm{b}}$ \\
& 2005 & 5.82 & $0.02^{\mathrm{b}}$ \\
Carabidae $^{\mathrm{a}}$ & 2004 & 2.44 & 0.1 \\
& 2005 & 10.56 & $0.002^{\mathrm{b}}$ \\
Chrysomelidae $^{\mathrm{a}}$ & 2004 & 1.02 & 0.3 \\
& 2005 & 0.33 & 0.5 \\
Curculionidae $^{\mathrm{a}}$ & 2004 & 0.04 & 0.8 \\
Formicidae $^{\mathrm{a}}$ & 2005 & 1.65 & 0.2 \\
Nabidae $^{\mathrm{a}}$ & 2004 & 1.03 & 0.3 \\
& 2005 & 0.17 & 0.6 \\
& 2004 & 0.84 & 0.3 \\
\end{tabular}

${ }^{\text {a }}$ Degrees of freedom $=4$

b Significant difference at $\alpha=0.05$

and CP2 fields $\left(t_{1,24}=6.1, \mathrm{P}=0.02\right)$. Improved CP10 and CP2 fields produced $0.7 \pm 0.5 \mathrm{~g} /$ field more biomass than CP25 fields. CRP fields had greater biomass compared to wheat fields in Jul. $2005\left(t_{1,24}=7.5, \mathrm{P}=0.01\right)$. CRP fields produced $0.7 \pm 0.5 \mathrm{~g} /$ field more biomass than wheat fields.

Insect-prey counts did not vary by sampling occasion in 2004 (Table 2) (Fig. 3b). In Jun. CRP fields produced greater insect-prey counts compared to wheat $\left(t_{1,24}=13.8, \mathrm{P}=0.001\right)$. CRP fields produced an estimated effect size of $1086.8 \pm 292$ insect-prey/field in Jun. CP10 fields also produced more insect-prey compared to CP2, improved CP10 and CP25 $\left(t_{1,24}=\right.$ $5.6, \mathrm{P}=0.02)$. CP10 fields produced an estimated effect size of $536.0 \pm 226.2$ insect-prey/ field in Jul. Insect-prey counts varied by sampling occasion in 2005 (Table 2) (Fig. 3b); however, there were no differences between CRP and wheat in Jun. In Jul., CRP fields produced greater insect-prey counts compared to wheat $\left(t_{1,24}=4.6, \mathrm{P}=0.04\right)$ with an estimated effect size of $863.4 \pm 402.0$ insect-prey/field.

\section{INVERTEBRATE FAMILIES}

We detected few differences between sampling occasions in Family counts in 2004 [Acrididae (Fig. 4a), Carabidae (Fig. 4b), Chrysomelidae (Fig. 4c), Curculionidae (Fig. 4d), Formicidae (Fig. 4e) and Nabidae (Fig. 4f)] (Table 2). Acrididae counts varied by sampling occasion in 2004 (Table 2); however, there were no differences between CRP and wheat in Jun. or Jul. In Jul. there were fewer Carabidae in CP10 fields compared to the remaining Conservation Practices $\left(t_{1,24}=23.0, \mathrm{P}=0.0001\right)$. Improved CP10, CP2 and CP25 fields in Jul. produced $195.4 \pm 79.7$ more Carabidae/field compared to CP10 fields. In Jul., CRP fields produced more Formicidae than wheat fields $\left(t_{1,24}=11.1, \mathrm{P}=0.003\right)$ with $207.1 \pm$ 121.0 more Formicidae/field in CRP fields than wheat fields. Improved CP10 and CP2 fields produced $222.3 \pm 105.8$ more Formicidae/field than CP10 fields in Jul. 


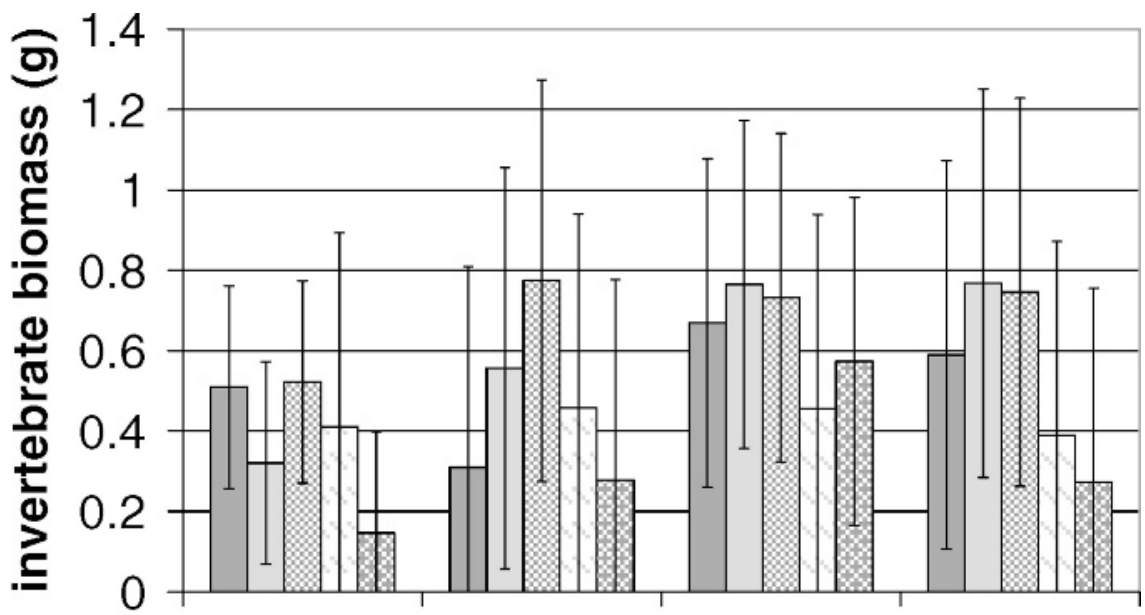

June 2004 July 2004 June 2005 July 2005

$\square$ CP10 $\square$ imp. CP10 圆CP2 $\square$ CP25 图 wheat

a)

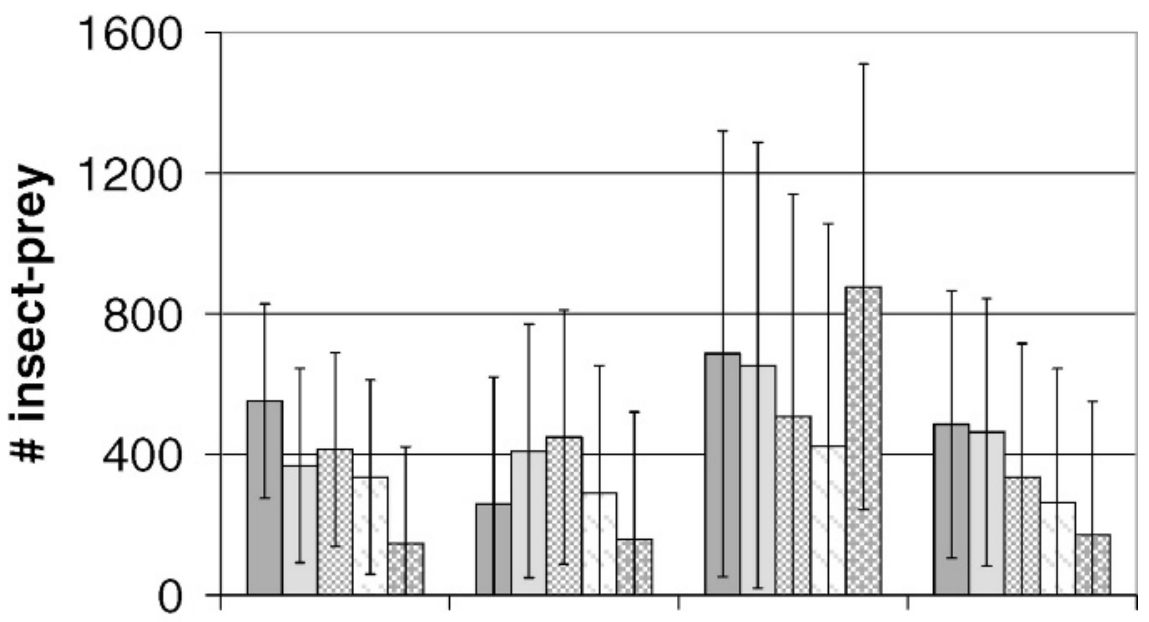

June 2004 July 2004 June 2005 July 2005

$\square$ CP10 $\square$ imp. CP10 圆 CP2 $\square$ CP25 图 wheat

b)

Fig. 3.-Least square mean estimates $( \pm 95 \% \mathrm{CI})$ for invertebrate biomass sampled per field and number of insect-prey ( $\pm 95 \%$ CI $)$ sampled per field in western Kansas, Jun. and Jul., 2004 and 2005 


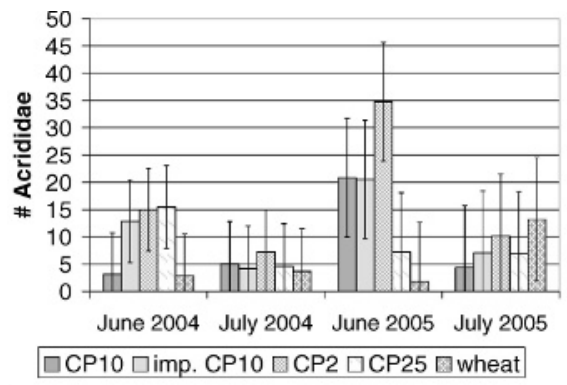

a)

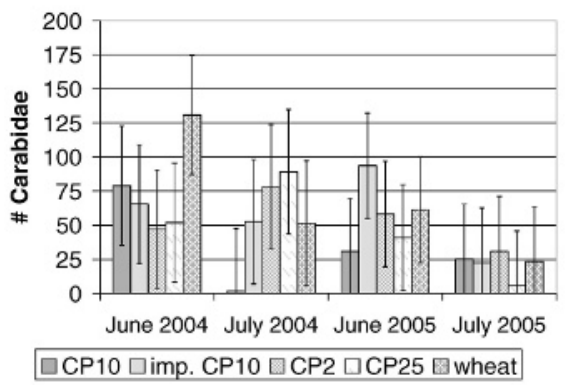

b)

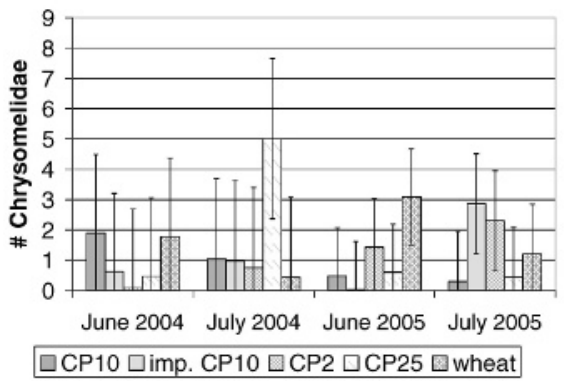

c)

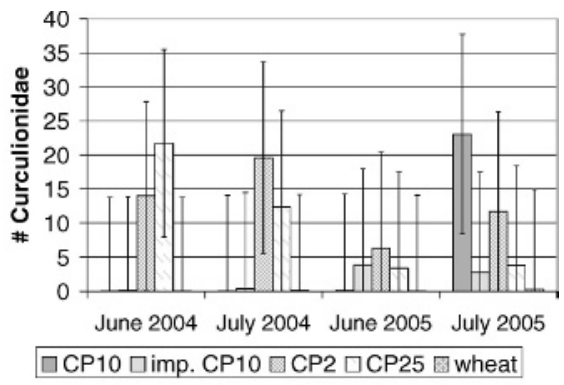

d)

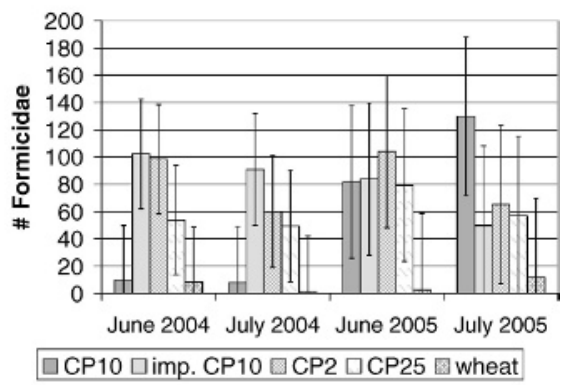

e)

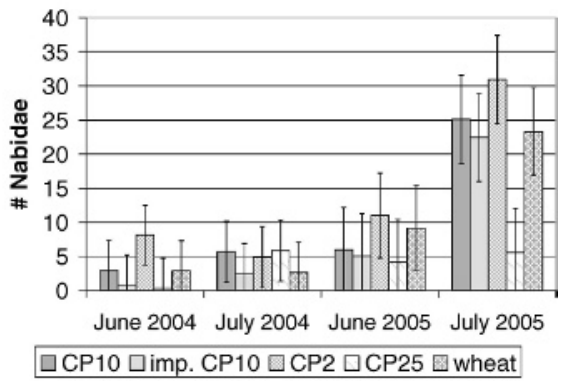

f)

Fig. 4.-Least square mean estimates $( \pm 95 \%$ CI $)$ for the number of a) Acrididae, b) Carabidae, c) Chrysomelidae, d) Curculionidae, e) Formicidae, and f) Nabidae sampled per field in western Kansas, Jun. and Jul., 2004 and 2005

Few differences were detected between sampling occasions in Family counts in 2005 [Chrysomelidae (Fig. 4c), Curculionidae (Fig. 4d), Formicidae (Fig. 4e) and Nabidae (Fig. 4f)] (Table 2). Acrididae counts varied by sampling occasion in 2005 (Table 2), but there were no differences between CRP and wheat in Jun. or Jul. Carabidae counts varied by sampling occasion in 2005 (Table 2) (Fig. 4b); however, there were no differences between CRP and wheat in Jun. In Jul., CP2 and improved CP10 fields had more Carabidae than CP25 fields $\left(t_{1,24}=5.2, \mathrm{P}=0.03\right)$. These fields produced $44.0 \pm 37.8$ more Carabidae/field than CP25 fields. In Jun. there were fewer Formicidae counts in the wheat fields compared 
to the CRP fields $\left(t_{1,24}=10.8, \mathrm{P}=0.003\right)$. Within the Conservation Practices, CP10 fields produced $392.2 \pm 233.7$ more Formicidae/field than the remaining Conservation Practices. However, in Jul. there were no differences between CRP and wheat.

\section{INVERTEBRATE ORDERS}

We detected few differences between sampling occasions in Order counts in 2004 [Coleoptera (Fig. 5b), Hemiptera (Fig. 5c), Homoptera (Fig. 5d), and Hymenoptera (Fig. 5e)] (Table 3). Araneae counts varied by sampling occasion in 2004 (Table 3) (Fig. 5a). Additionally, CRP fields had greater Araneae counts than wheat fields in Jun. ( $t_{1,24}$ $=9.7, \mathrm{P}=0.005)$. In Jun. CRP fields produced $64.1 \pm 40.2$ more Araneae/field than wheat fields, and CRP fields produced $38.4 \pm 28.3$ more Araneae/field than wheat fields in Jul. There were fewer Coleoptera in wheat fields compared to the CRP fields $\left(t_{1,24}=17.1, \mathrm{P}=\right.$ 0.0006) in Jul. CRP fields produced $271.1 \pm 128.3$ more Coleoptera/field than wheat fields. Improved CP10, CP2 and CP25 fields produced 136.0 \pm 112.9 more Coleoptera/field a than CP10 fields. In Jun., wheat fields had fewer Homoptera compared to the CRP fields $\left(t_{1,24}=\right.$ 38.8, $\mathrm{P}<0.0001)$. CRP fields produced $951.0 \pm 298.9$ more Homoptera/field than wheat fields. Wheat fields had fewer Hymenoptera compared to CRP fields in Jun. $\left(t_{1,24}=4.9, \mathrm{P}=\right.$ $0.04)$ and Jul. $\left(t_{1,24}=18.4, \mathrm{P}=0.0004\right)$. In Jun. the CRP fields produced $951.0 \pm 298.9$ more Hymenoptera/field than wheat fields. In Jul. the CRP fields produced $313.9 \pm 143.1$ more Hymenoptera/field than wheat fields. Lepidoptera larvae counts varied by sampling occasion in 2004 (Fig. 5f), yet, there were no differences between CRP and wheat in Jun. In Jul. CP25 fields produced more Lepidoptera larvae than improved CP10 and CP2 fields $\left(t_{1,24}=7.2, \mathrm{P}=0.01\right)$. CP25 fields produced $15.9 \pm 11.5$ more Lepidoptera larvae/field than improved CP10 and CP2 fields. Orthoptera counts varied by sampling occasion in 2004 (Table 3) (Fig. 5g), but there were no differences between CRP and wheat in Jun. or Jul.

Few differences were detected between sampling occasions in Order counts in 2005 [Coleoptera (Fig. 5b), Hemiptera (Fig. 5c), Hymenoptera (Fig. 5e), Lepidoptera larvae (Fig. 5f) and Orthoptera (Fig. 5g)] (Table 3). Araneae counts varied by sampling occasion in 2005 (Table 3) (Fig. 5a), but there were no differences between CRP and wheat in Jun. In Jul. wheat fields had fewer Araneae than CRP fields $\left(t_{1,24}=25.7, \mathrm{P}<0.0001\right)$. Improved CP10 fields had fewer Araneae than CP2 fields $\left(t_{1,24}=4.6, \mathrm{P}=0.04\right)$, and CP25 fields had fewer Araneae than improved CP10 and CP2 fields $\left(t_{1,24}=20.4, \mathrm{P}=0.0002\right)$. CRP fields produced $116.4 \pm 45.8$ more Araneae/field than wheat fields. Improved CP10, CP2 and CP25 fields produced $15.3 \pm 13.9$ more Araneae/field compared to CP10 fields. Improved CP10 and CP2 fields produced $64.8 \pm 28.0$ more Araneae/field than CP25 fields. In Jul., CRP fields had greater Coleoptera counts than wheat fields $\left(t_{1,24}=13.3, \mathrm{P}=0.001\right)$. CP25 fields had fewer Coleoptera than improved CP10 and CP2 fields $\left(t_{1,24}=6.4, \mathrm{P}=0.02\right)$. CRP fields produced 253.0 \pm 135.6 more Coleoptera/field than wheat fields and improved CP10 and CP2 fields produced $107.2 \pm 83.1$ more Coleoptera/field than CP25 fields. In Jun. there were no differences between CRP and wheat; however, in Jul., there were more Hemiptera in wheat fields than CRP fields $\left(t_{1,24}=10.2, \mathrm{P}=0.004\right)$. Wheat fields produced $238.8 \pm 146.4$ more Hemiptera/field than CRP fields. Homoptera counts did vary by sampling occasion in 2005 (Table 3) (Fig. 5d). In Jun., CRP fields produced more Homoptera than wheat fields $\left(t_{1,24}=8.3, \mathrm{P}=0.009\right)$. CRP fields produced $1365.4 \pm 923.7$ more Homoptera/field than wheat fields. There were no differences between CRP and wheat in Jul. In Jun., there were fewer Hymenoptera in wheat fields compared to CRP fields $\left(t_{1,24}=9.4, \mathrm{P}=0.006\right)$. CRP fields produced $409.6 \pm 261.4$ more Hymenoptera $/$ field than wheat fields. In Jul. there were greater Hymenoptera in CP10 fields compared to the 


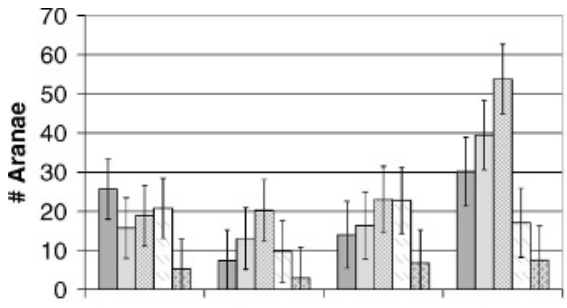

June 2004 July 2004 June 2005 July 2005 $\square$ CP10 $\square$ imp. CP10 $\square$ CP2 $\square$ CP25 $\square$ wheat

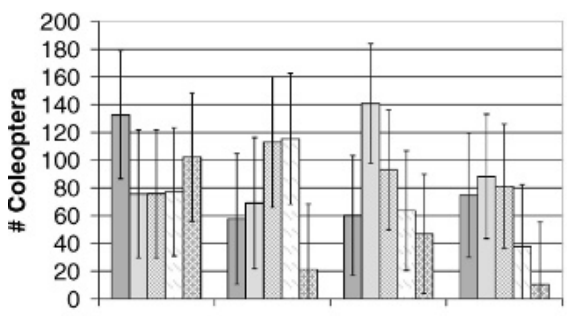

June 2004 July 2004 June 2005 July 2005
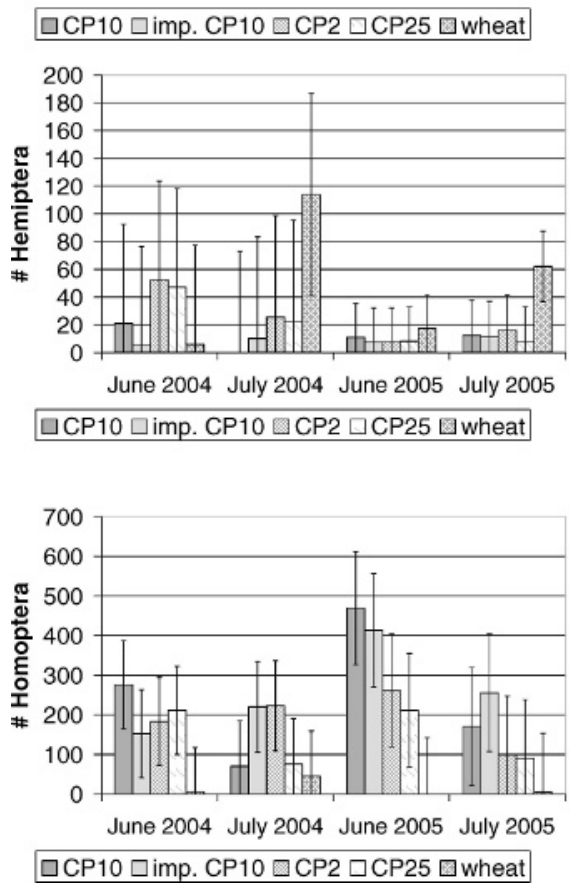

Fig. 5.-The least square mean estimates $( \pm 95 \%$ CI $)$ for the number of a) Araneae, b) Coleoptera, c) Hemiptera, d) Homoptera, e) Hymenoptera, f) Lepidoptera larvae, and g) Orthoptera sampled per field in western Kansas, Jun. and Jul., 2004 and 2005
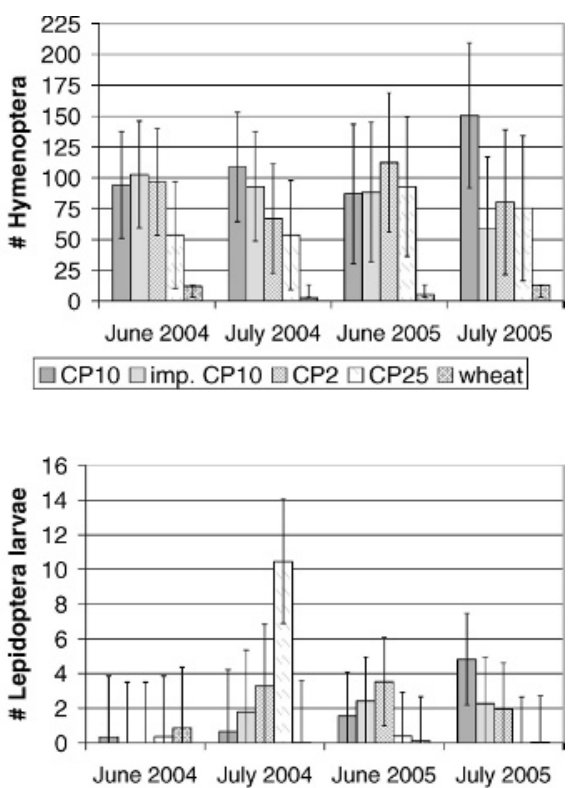
$\square \mathrm{CP} 10 \square \mathrm{imp} . \mathrm{CP} 10 \square \mathrm{CP} 2 \mathrm{CP} 25 \square$ wheat

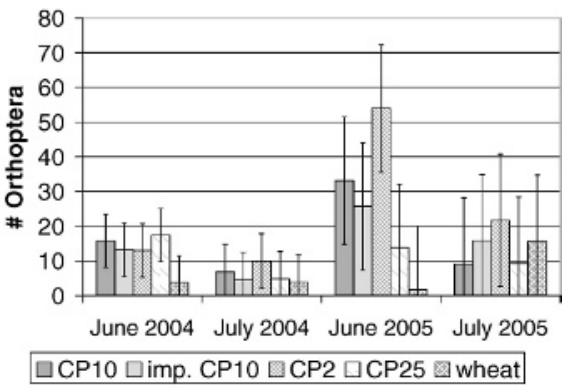


TABle 3.-Test statistics (F-test) for mean abundances measured in the four Conservation Practices and wheat for seven insect Orders in western Kansas, Jun. and Jul., 2004 and 2005

\begin{tabular}{lccc}
\hline \hline \multicolumn{1}{c}{ Order } & Year & Between sampling period & P-value \\
\hline Araneae $^{\mathrm{a}}$ & 2004 & 7.6 & $0.008^{\mathrm{b}}$ \\
Coleoptera $^{\mathrm{a}}$ & 2005 & 21.55 & $<0.0001^{\mathrm{b}}$ \\
& 2004 & 1.47 & 0.2 \\
Hemiptera $^{\mathrm{a}}$ & 2005 & 2.48 & 0.1 \\
& 2004 & 0.1 & 0.7 \\
Homoptera $^{\mathrm{a}}$ & 2005 & 2.05 & 0.1 \\
& 2004 & 1.26 & 0.2 \\
Hymenoptera $^{\mathrm{a}}$ & 2005 & 9.71 & $0.003^{\mathrm{b}}$ \\
Lepidoptera larvae $^{\mathrm{a}}$ & 2004 & 0.26 & 0.6 \\
Orthoptera $^{\mathrm{a}}$ & 2005 & 0.01 & 0.9 \\
& 2004 & 7.26 & $0.01^{\mathrm{b}}$ \\
& 2005 & 0.06 & 0.8 \\
\end{tabular}

${ }^{\text {a }}$ Degrees of freedom $=4$

b Significant difference at $\alpha=0.05$

remaining Conservation Practices $\left(t_{1,24}=4.59, \mathrm{P}=0.04\right)$. CP10 fields produced $280.4 \pm$ 256.5 more Hymenoptera/field than the remaining Conservation Practices.

\section{Discussion}

With management practices and growing conditions ranging widely across regions, plus the smaller geographical scales of this study, evaluating the performance of conservation programs is not a simple matter. The majority of our fields were large and topo-edaphic conditions varied across the field which most likely influenced the vegetation even within the scale we were measuring. However, structural characteristics of our CRP sites are similar to those reported in other studies. Height-density indexes at CRP study sites in northern Missouri averaged $3.4 \mathrm{dm}$, bare ground cover averaged 2\% and forb cover averaged 12-18\% for 4-y-old CRP in Missouri (Burger et al., 1990). In one Nebraska CRP study, bare ground cover averaged 3-4\% and forb cover averaged 3-7\% (Delisle and Savidge, 1997). In a Texas study, bare ground cover averaged $11 \%$ and forb cover averaged $8 \%$ (McIntyre and Thompson, 2003). Our sites were most comparable with the northern Missouri study as height-density indexes averaged $3.0 \mathrm{dm}$, bare ground cover averaged $<10 \%$ and forb cover averaged $<20 \%$ but was highly variable. McCoy et al. (2001) found forb cover in Missouri CRP to average 20\% even in 9-year-old CRP fields. However, this did not seem to hold true for our fields as it seems forb cover at our sites (particularly CP25) declined as the fields aged. The loss of forbs over time has been demonstrated previously (Hall and Willig, 1994; Greenfield et al., 2002) and remains a difficult issue in the future management of these fields due to their specific management requirements.

Amount of bare ground and forb cover are often good indicators of brood habitat quality for farmland gamebirds. Bare ground, which is an important determinant in the mobility of small chicks, was fairly low, usually $<10 \%$ on all our study plots in CRP. For CP10 fields, this was even less with the average bare ground ranging from 1 to $5 \%$. In the case of bare ground, gamebirds require habitat that is open to allow for unimpeded movement, but not too open so that chicks are highly visible. Continuing with the factors of brood habitat 
quality, CP10 fields had a decrease in forbs between Jun. and Jul. A few of the Jun. 2004 CP10 fields had considerable populations of wild sweet clover. These plants had mostly senesced by the Jul. sampling occasion which was reflected in the drop in forb cover. Conversely, wheat fields had an increase in forb cover. Mid- to late-Jun. 2004 was unusually rainy which helped to foster weed growth in harvested wheat fields and reinvigorated desiccated forbs in CRP fields. Studies show wheat fields which are not sprayed with herbicides and have a greater percentage of weed cover are sources of high insect-prey availability (Chiverton and Sotherton, 1991; Taylor et al., 2006). As for the vegetation height which gives us a clue as to chick concealment, none of the Conservation Practices varied in height; however, all of these practices were greater than harvested wheat fields. Still, these harvested fields are very open at ground level and the annual weeds found at these sites are an excellent substrate for the types of insects the growing chicks need and the vegetation height, while shorter, may be tall enough for the concealment of young gamebird chicks.

However, habitat "quality" is much more complex than simple forb and bare ground cover. Invertebrate abundances of key insect-prey items were not significantly different among the four CRP types examined in this study; however, the ability of young gamebird chicks to access this invertebrate protein may vary. Pheasant chicks are known to utilize CP10 fields (Rodgers, 1999) which our study suggests have bare ground cover $<10 \%$. However, the use of CP10 fields have not been documented for bobwhite chicks in this area; perhaps, as the result of the inability of chicks to adequately move throughout these habitats.

Fields (2001) determined that improved CP10 fields had greater invertebrate biomass compared to CP10 fields in Jun., Jul. and Aug. In her study, improved CP10 fields had 0.6 and $0.8 \mathrm{~g}$ greater invertebrate biomass than CP10 fields in Jun. and Jul., respectively. Improved CP10 fields in our study were generally greater than CP10 fields by an average $0.2 \mathrm{~g}$. However, biomass in our CP10 fields was much greater than reported by Fields (2001). Compared to CP2 in northern Missouri, invertebrate biomass was considerably greater, ranging from $0.57-0.77 \mathrm{~g}$ in CP2 in Kansas and $0.44-0.54 \mathrm{~g}$ in CP2 in northern Missouri (Burger et al., 1993). Additionally, abundance of several Orders was considerably greater at our sites compared to the Missouri sites (Homoptera, 3-9 times greater; Hemiptera, 2-13 times greater; Orthoptera, 9-53 times greater; Coleoptera, 29-43 times greater). These results are interesting given that the forb cover was very similar between the two sites. McIntyre and Thompson (2003) reported CP2 fields in Texas were dominated by Araneae, Coleoptera and Orthoptera whereas our sites had considerable Coleoptera populations and our Araneae estimates were much lower than those reported by McIntyre and Thompson (2003). Additionally, McIntyre and Thompson (2003) reported very low estimates of Lepidoptera, whereas our field sites had considerably greater abundance of Lepidoptera.

CP10 fields, which in several cases had greater invertebrate counts relative to the other Conservation Practices in Jun., frequently demonstrated drops in invertebrates during Jul. For example, there were major drops in the invertebrate biomass and abundance estimates for Araneae and Coleoptera. Even though the majority of the pheasant hatch in western Kansas is in early Jun., chicks resulting from second nest attempts would be hindered by this reduction if they were to use CP10 fields as brood habitat. Conversely, Conservation Practices that incorporated forbs in some way (improved CP10, CP2 and CP25 fields) had less considerable drops and even increases in invertebrate biomass and invertebrate abundances of certain Families such as Nabidae and Orders including Lepidoptera. The high Jun. invertebrate counts in CP10 fields may have been the result of abundant sweet 
clover or field age. CP10 fields were older and may have more stable invertebrate populations compared to the younger Conservation Practices.

CP25 fields also had a surprising drop in invertebrate abundance in 2005. Jul. 2005 CP25 fields had fewer invertebrate counts than the other Conservation Practices and had slightly more invertebrates than Jul. wheat fields. This is best demonstrated in the number of Chrysomelidae. In 2004 CP25 fields had on average 5 Chrysomelidae sampled compared to an average of 1-2 leaf beetles for the other Conservation Practices. In 2005 CP25 fields had on average 0.5 Chrysomelidae sampled compared to 3 leaf beetles for CP2 fields. This may be a result of the drop in forbs from 2004 to 2005.

CRP fields had a tendency to produce more quality insect-prey than wheat, except when compared to unharvested wheat fields. Unharvested wheat fields were rich with insect-prey. Unfortunately, we only have one season of unharvested wheat data therefore it is impossible to determine if this is the general trend or a $1 \mathrm{y}$ abnormality. This also contrasts with the extremely low insect abundance and diversity reported in wheat fields in the U.K. (Potts, 1986). There mortality of gamebird chicks has been linked to increased use of pesticides in cereal fields and loss of the forb community (Potts, 1986).

With the CRP Conservation Practices, CP10 fields in 2004 demonstrate a huge drop in quality prey, whereas the other practices remained stable or increased. In 2005 all field types dropped in prey count during Jun. to Jul. Overall, CRP fields had greater invertebrate prey availablity compared to wheat fields. For certain Families (e.g., Acrididae, Chrysomelidae, Nabidae, Curculionidae and Formicidae) and Orders (e.g., Araneae, Coleoptera, Homoptera, Hymenoptera, Lepidoptera larvae and Orthoptera), the estimated effect size was much larger in CRP fields compared to wheat. Additionally, the estimated effect size for insect biomass was much larger in CRP fields compared to wheat fields. The only Family which was more prevalent in wheat fields compared to CRP fields was Carabidae. However, when wheat fields had populations of forbs (especially Kochia spp.), wheat fields had respectable populations of Hemiptera, an excellent insect-prey.

Our data suggests that in a variable environment, diversity in available conservation options might be the best for providing quality brood habitat. It is apparent from the results we observed in wheat that it can provide some good habitat, but depending on the year that habitat might disappear early or late depending on weather conditions. Our data also suggests that some of the ephemeral nature of forbs and some groups of insects associated with each of the CP types might result in some of these practices being better than others in particular years, but also over the life of the stand.

A mix of CRP practices planted across the landscape may mitigate some of the issues we have addressed. With the implementation of Kansas Conservation Priority Areas (CPA) for Pheasant, Bobwhite and Prairie-chicken targeting areas of enrollment in this study region (particularly Gove and Ness Counties), the opportunity to establish a variety of CRP mixes in a localized area exists. However, the current ranking for potential contracts in these areas favors CP25 compared to the other mixes. Because CP25 is a rare and declining habitat mix, this conservation practice has very particular management considerations such as prescribed burning, mowing or light disking of the field at certain ages (USDA, 2005). Because of the loss of forbs and issues associated with the loss, this focus on CP25 in these Priority Areas may need to be reconsidered.

Acknowledgments. -We wish to thank Valena Hickert, Jessica Bitner, Randy Rodgers, Roger Applegate, Bill Palmer, Robert Cooper, Farm Service Agency employees of Trego, Gove and Ness counties and the many local landowners who assisted in this project. This research has been supported by the Kansas 
Federal Aid in Wildlife Restoration W-62-R1 and the Warnell School of Forestry and Natural Resources, University of Georgia.

\section{Literature Cited}

Best, L. B., H. Campa, III, K. E. Kemp, R. J. Robel, M. R. Ryan, J. A. Savidge, H. P. Weeks, Jr. and S. R. Winterstein. 1998. Avian abundance in CRP and crop fields during winter in the Midwest. Am. Midl. Nat., 139:311-325.

Buffington, M. L. and R. A. Redak. 1998. A comparison of vacuum sampling vs. sweep-netting for arthropod biodiversity measurements in California coastal sage scrub. J. Insect Conserv., 2:99-106.

Burger, L. W., Jr., E. W. Kurzejeski, T. V. Dailey and M. R. Ryan. 1990. Structural characteristics of vegetation in CRP fields in northern Missouri and their suitability as bobwhite habitat. Trans. $N$. A. Wild. Nat. Resour. Conf., 55:74-83.

,--1 - $\longrightarrow$ - 1993. Relative invertebrate abundance and biomass in Conservation Reserve Program plantings in northern Missouri, p. 102-108. In: K. E. Church and T. V. Dailey (eds.). Quail III: National Quail Symposium. Kansas Department of Wildlife and Parks, Pratt, KS.

Chiverton, P. A. and N. W. Sotherton. 1991. Effects on beneficial arthropods of the exclusion of herbicides from cereal crop edges. J. Appl. Ecol., 28:1027-1039.

Cooper, R. J. And R. C. Whitmore. 1990. Arthropod sampling methods in ornithology. Stud. Avian Biol., 13:29-37.

Delisle, J. M. And J. A. SAvidge. 1997. Avian use and vegetation characteristics of Conservation Reserve Program fields. J. Wild. Manage., 61:318-325.

Dietrick, E. J. 1961. An improved backpack motor fan for suction sampling of insect populations. J. Econ. Entomol., 54:394-395.

Doxon, E. D. 2005. Feeding ecology of ring-necked pheasant (Phasianus colchicus) and northern bobwhite (Colinus virginianus) chicks in vegetation managed using Conservation Reserve Program (CRP) practices. M. S. Thesis, University of Georgia, Athens, GA, USA. 133 p.

FIeLDS, T. L. 2001. Arthropod biomass and diversity in interseeded and grassland CRP managed for lesser prairie chickens (Tympanuchus pallidicinctus) and ring-necked pheasants (Phasianus colchicus) in western Kansas. Kansas Wildlife and Parks Report, Hays, KS. 26 p.

Greenfield, K. C., J. L. W. Burger, M. J. Chamberlain and E. W. Kurzejeski. 2002. Vegetation management practices on Conservation Reserve Program fields to improve northern bobwhite habitat quality. Wild. Soc. Bull., 30:527-538.

Hall, D. L. and M. R. Willig. 1994. Mammalian-species composition, diversity, and succession in Conservation Reserve Program grasslands. Southw. Nat., 39:1-10.

Handley, C. O. 1931. Food of the young, p. 159-164. In: H. L. Stoddard (ed.). Bobwhite Quail: it's habits, preservation, and increase. Charles Scribner's Sons, NY, USA.

HiLl, D. A. 1985. Feeding ecology and survival of pheasant chicks on arable farmland. J. Appl. Ecol., 22:645-654.

Hughes, J. P., R. J. Robel and K. E. Kemp. 2000. Factors influencing mourning dove nest success in CRP fields. J. Wild. Manage, 64:1004-1008.

Hull, S. D., R. J. Robel and K. E. Kemp. 1996. Summer avian abundance, invertebrate biomass, and forbs in Kansas CRP. Prairie Natr., 28:1-12.

Jackson, J. R., G. A. Hurst and E. A. Glusing. 1987. Abundance and selection of invertebrates by northern bobwhite chicks. Proc. Annu. Conf. Southeast. Fish and Wildl. Agencies, 41:303-310.

Jamison, B. E., R. J. Robel, J. S. Pontius and R. D. Applegate. 2002. Invertebrate biomass: associations with lesser prairie-chicken habitat use and sand sagebrush density in southwestern Kansas. Wild. Soc. Bull., 30:517-526.

Johnson, D. H. and M. D. Schwartz. 1993. The Conservation Reserve Program and grassland birds. Conserv. Biol., 7:934-937.

Kansas Department of Wildlife and Parks. 2003. Establishing grasslands for prairie birds. Kansas Department of Wildlife and Parks, Hays, KS. 4 p. 
Kansas Geological Survey. 2003. Ness County land cover. Lawrence, KS.

King, J. W. And J. A. SAvidge. 1995. Effects of the Conservation Reserve Program on wildlife in southeast Nebraska. Wild. Soc. Bull., 23:377-385.

LANDers, J. L. ANd B. S. Mueller. 1986. Bobwhite quail management: a habitat approach. Tall Timbers Research Station, Miscellaneous Publication Number 6, Tallahassee, FL. 39 p.

McCoy, T. D., E. W. Kurzejeski, L. W. Burger, JR. ANd M. R. Ryan. 2001. Effects of Conservation Practice, mowing, and temporal changes on vegetation structure on CRP fields in northern Missouri. Wild. Soc. Bull., 29:979-987.

McIntyre, N. E. And T. R. Thompson. 2003. A comparison of Conservation Reserve Program habitat plantings with respect to arthropod prey for grassland birds. Am. Midl. Nat., 150:291-301.

Moreby, S. J. 2003. Birds of lowland arable farmland: the importance and identification of invertebrate diversity in the diet of chicks, p. 21-25. In: H. van Emden and M. Rothschild (eds.). Insect and Bird Interactions. Intercept, Andover, Hampshire, UK.

National Agricultural Statistics Service. 2002. Agricultural Statistics for 2002. USDA, General Printing Office, Washington, DC.

Potтs, G. R. 1986. Partridge: pesticides, predation and conservation. Collins, London, UK. 256 p.

Robel, R. J., J. N. Briggs, A. D. Dayton and L. C. Hilbert. 1970. Relationships between visual obstruction measurements and weight of grassland vegetation. J. Range Manage., 23:295-297.

Rodgers, R. D. 1999. Why haven't pheasant populations in western Kansas increased with CRP? Wild. Soc. Bull., 27:654-665.

SAS InstituTe. 1999. SAS/STAT software, version 8.2. SAS Institute, Cary, North Carolina, USA.

Stoner, K. J. L. AND A. Joern. 2004. Landscape vs. local habitat scale influences to insect communities from tallgrass prairie remnants. Ecol. Appl., 14:1306-1320.

Taylor, R. L., B. D. Maxwell and R. J. Boik. 2006. Indirect effects of herbicides on bird food resources and beneficial arthropods. Agric. Ecosyst. Environ., 116:157-164.

United States Department of Agriculture. 2001. The Conservation Reserve Program. PA-1603. FSA, USDA, Washington, D. C., USA.

2005. Final CRP Interim Rule. FSA, USDA, Washington, D. C., USA.

2006. Kansas CRP acreage. FSA, USDA, Washington, D. C., USA.

Weather Data Library. 2005. Precipitation summaries for Kansas counties. Manhattan, KS.

Whitmore, R. W., K. P. Pruess and R. E. Gold. 1986. Insect food selection by 2-week-old ring-necked pheasant chicks. J. Wild. Manage., 50:223-228.

Wiens, J. A. And J. T. Rotenberry. 1979. Diet niche relationships among North American grassland and shrubsteppe birds. Oecol., 42:252-292. 
APPENDIX 1.-Insects were classified as greater or lesser quality insect-prey depending on their occurrence in the diet of bobwhite or pheasant chicks as determined by Doxon (2005)

\begin{tabular}{ll}
\hline \hline Greater quality & Lesser quality \\
\hline Order Araneae & Order Acari \\
Order Blattodea & Family Ixodidae \\
Family Blattellidae & Family Trombididae \\
Order Coleoptera & Order Coleoptera \\
Family Carabidae & Family Coccinellidae \\
Family Chrysomelidae & Family Meloidae \\
Family Curculionidae & Family Melyridae \\
Family Elateridae & Order Diptera \\
Family Scarabaeidae & Family Chloropidae \\
Family Staphylinidae & Family Culicidae \\
Family Tenebrionidae & Order Ephemeroptera \\
Order Collembola & Order Hemiptera \\
Order Diptera & Family Anthocoridae \\
other Diptera & Family Coreidae \\
Order Hemiptera & Family Pentatomidae \\
Family Berytidae & Family Reduviidae \\
Family Lygaeidae & Order Homoptera \\
Family Nabidae & Family Cicadidae \\
Order Homoptera & Order Hymenoptera \\
Family Aphididae & Family Apidae \\
Family Cicadellidae & Family Halicidae \\
Family Membracidae & Family Specidae \\
Order Hymenoptera & Order Julida \\
Family Formicidae & Order Lepidoptera \\
Family Ichneumonidae & adult Lepidoptera \\
Order Lepidoptera & Order Odonata \\
Lepidoptera larvae & Order Orthoptera \\
Order Neuroptera & Family Tettigoniidae \\
Neuroptera larvae & Order Phasmatodea \\
Order Orthoptera & Family Heteronemiidae \\
Family Acrididae & \\
Family Gryllidae & \\
\hline & \\
\hline & \\
\hline & \\
\hline & \\
\hline
\end{tabular}

